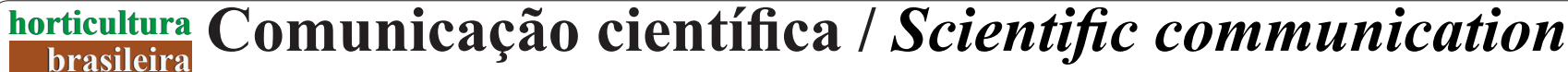

FRANÇA CFM; RIBEIRO WS; SILVA FC; COSTA LC; RÊGO ER; FINGER FL. 2015. Hydrocooling on postharvest conservation of butter lettuce. Horticultura Brasileira 33: 383-387. DOI: http://dx.doi.org/10.1590/S0102-053620150000300018

\section{Hydrocooling on postharvest conservation of butter lettuce}

\author{
Christiane FM França ${ }^{1}$; Welington S Ribeiro ${ }^{1}$; Fernanda C Silva ${ }^{1}$; Lucas C Costa ${ }^{1}$; Elizanilda R Rêgo ${ }^{2}$; \\ Fernando L Finger ${ }^{1}$ \\ ${ }^{1}$ Unversidade Federal de Viçosa, UFV-Depto. Fitotecnia, Viçosa-MG, Brasil; chrisagroufv@gmail.com; wellingtisouto@yahoo.com. \\ br; nandsilva@yahoo.com.br; costalc@ymail.com; ffinger@ufv.br; ${ }^{2}$ Universidade Federal da Paraíba, UFPB-CCA, Areia-PB, Brasil; \\ elizanilda@cca.ufpb.br
}

\begin{abstract}
Lettuce is a vegetable highly susceptible to water loss, which reduces its shelf life and increases the final cost to the consumer. The aim of this study was to evaluate the effects of hydrocooling on the postharvest shelf life of butter lettuce 'Vitória de Santo Antão'. The lettuce heads, after selection, were subjected to the following treatments: $\mathrm{T} 1=$ hydrocooling followed by storage at $5^{\circ} \mathrm{C}$ in the cold chamber; $\mathrm{T} 2=$ storage in the cold chamber at $5^{\circ} \mathrm{C}$ without hydrocooling; $\mathrm{T} 3=$ hydrocooling followed by storage at $22^{\circ} \mathrm{C}$ and $\mathrm{T} 4=$ storage at $22^{\circ} \mathrm{C}$ without hydrocooling. We determined the shelf life, leaves mass loss, chlorophyll content, relative water content, total soluble sugars content, reducing sugars, non-reducing sugars and starch. The data were analyzed in split plot in a randomized block design with four replications. The hydrocooling was effective in slowing down the visual wilting of the leaves at 5 and $22^{\circ} \mathrm{C}$, extending the shelf life. The hydrocooling combined with storage at $5^{\circ} \mathrm{C}$ maintained the leaves water balance, keeping them hydrated during storage, causing an increase of $20 \%$ in the marketing of the product, from 5 days in lettuces without hydrocooling, to 6 days when these were subjected to hydrocooling. No effect of hydrocooling in the chlorophyll content, total soluble sugars, reducing sugars, non-reducing sugars and starch of leaves was observed in any of the storage temperatures. The hydrocooling at $4^{\circ} \mathrm{C}$ during 5 minutes, followed by storage at $5^{\circ} \mathrm{C}$ is an effective technique to maintain the leaves water balance, promoting longer shelf life.
\end{abstract}

Keywords: Lactuca sativa, cooling, shelf life, chlorophyll, carbohydrates.

\section{RESUMO}

Hidrorresfriamento na conservação pós-colheita de alface lisa

A alface é uma hortaliça altamente suscetível à perda de água, o que reduz sua vida de prateleira e aumenta o custo final para o consumidor. O objetivo desse trabalho foi avaliar o efeito do hidrorresfriamento na conservação pós-colheita da alface 'Vitoria de Santo Antão', do tipo lisa. As cabeças de alface, após seleção, foram submetidas aos seguintes tratamentos: $\mathrm{T} 1=$ hidrorresfriamento seguido de armazenamento a $5^{\circ} \mathrm{C}$ em câmara fria; $\mathrm{T} 2=$ armazenamento em câmara fria a $5^{\circ} \mathrm{C}$ sem hidrorresfriamento; $\mathrm{T} 3=$ hidrorresfriamento seguido de armazenamento a $22^{\circ} \mathrm{C} \mathrm{e} \mathrm{T4=} \mathrm{armazenamento} \mathrm{à} \mathrm{tempera-}$ tura de $22^{\circ} \mathrm{C}$ sem hidrorresfriamento. Avaliou-se a vida de prateleira, a perda de massa das folhas, teor de clorofila, teor relativo de água, teores de açúcares solúveis totais, açúcares redutores, açúcares não redutores e teor de amido. Os dados foram analisados em esquema de parcelas subdivididas, no delineamento em blocos casualizados, com quatro repetições. $\mathrm{O}$ hidrorresfriamento foi efetivo em retardar o murchamento visual das folhas a 5 e $22^{\circ} \mathrm{C}$, estendendo a vida de prateleira. $\mathrm{O}$ hidrorresfriamento aliado ao armazenamento a $5^{\circ} \mathrm{C}$ manteve o balanço hídrico das folhas, deixando-as hidratadas durante o armazenamento, promovendo um aumento de $20 \%$ no período de comercialização do produto, passando de 5 dias em alfaces não hidrorresfriadas, para 6 dias quando essas foram submetidas ao hidrorresfriamento. Não houve efeito do hidrorresfriamento nos teores de clorofila, açúcares solúveis totais, redutores, não redutores e amido das folhas em nenhuma das temperaturas de armazenamento. O hidrorresfriamento a $4^{\circ} \mathrm{C}$ por 5 minutos, seguido de armazenamento a $5^{\circ} \mathrm{C}$ é uma técnica eficiente em manter o balanço hídrico das folhas, promovendo uma maior vida de prateleira.

Palavras-chave: Lactuca sativa, resfriamento, vida de prateleira, clorofila, carboidratos.

(Recebido para publicação em 11 de julho de 2014; aceito em 23 de março de 2015) (Received on July 11, 2014; accepted on March 23, 2015)

$\mathrm{P}$ ostharvest losses of vegetables in Brazil are extensive and according to Vilela et al. (2003), they are from 35 to $40 \%$, being necessary to be reduced in order to achieve an adequate food supply for all Brazilian population.

Leafy vegetables are highly perishable and highly susceptible to water loss, which can be intensified by inadequate handling of temperature and air humidity in storage and marketing places, with consequent reduction in shelf life and increase in the final cost of the product to consumers (Álvares et al., 2007). In general water loss through transpiration determines, most of the times, quantitative and qualitative losses of vegetables (Finger \& Vieira, 1997; Finger et al., 2008).

Fresh vegetables, after harvesting, spend a period of time at room 
temperature, where they are supposed to be packaged and afterwards transported to the marketing place. During this period, these products may be under stress condition, such as acceleration of respiration and water loss because of physical damage during packing and transportation which result in shorter shelf life. According to Lill et al. (1990), for asparagus, most physiological, biochemical and molecular changes occur in the first three hours after harvesting. Thus, rapid cooling of these products immediately after harvesting is necessary, in order to reduce metabolic activity, reducing, this way, its rate of decay (Gillies \& Toivonen, 1995). Hydrocooling is one of pre-cooling methods which can be used in this case, and consists of removing with cold water, the so-called "field heat" of freshly harvested horticultural products (Wills et al., 2007). After harvesting and pre-cooling, keeping the cold chain is important, since this is one of the most effective ways to reduce losses in quality and quantity, and preserve food security of horticultural products (Kader, 2010).

Pre-cooling has proven to be effective in increasing postharvest shelf life of several horticultural products. Toivonen (1997), studying the use of pre-cooling method in broccoli conservation, observed that the heads remained firm for a longer period of time at $1^{\circ} \mathrm{C}$. Pre-cooling using cold water immersion also provided beneficial effects on the increase of parsley leaves shelf life, providing the maintenance of higher water content in the leaves during cold storage and reduction of fresh mass loss (Álvares et al., 2007). However, no information was found on hydrocooling effect, as pre-cooling method, for lettuce, regarding on leaves duration and physiological changes during storage. Thus, this experiment aimed to evaluate the effect of hydrocooling on the quality and postharvest shelf life of lettuce, stored at room temperature or under refrigeration.

\section{MATERIAL AND METHODS}

The experiment was carried out at Federal University of Viçosa (UFV),
Viçosa, Minas Gerais State, Brazil (20॰45' S, 42 $52^{\prime} \mathrm{W}$, altitude $648 \mathrm{~m}$ ) using butter lettuce heads (Lactuca sativa), cultivar 'Vitória de Santo Antão', grown in a experimental field, following all cultural management recommended until commercial harvesting time, when the head showed maximum size and no senescent leaves. Harvesting of heads was performed during the morning from 7 to $7 \mathrm{~h}$ 30, during January and February, 2011, being transported immediately to the Postharvest Laboratory, where heads weighing between 300 and 400 $\mathrm{g}$, with no signs of wilt, yellowing or any incidence of decay, were selected.

Hydrocooling was performed by immersing the heads in a mixture of ice and water in the proportion of $1: 3(\mathrm{v} / \mathrm{v})$ at $4{ }^{\circ} \mathrm{C}$. Previously, a test for determination of optimum hydrocooling time was carried out. For this, 22 lettuce heads were immersed in water under these conditions. Every 5 minutes, during 55 minutes, 2 lettuce heads were removed from water-ice mixture, and their temperature was measured. Internal head temperature was determined using a digital thermometer (Quartz Digi-Thermo model EAI TM120). Optimum hydrocooling time was established when the temperature of lettuce reached stability, that means, when no more significant reduction of lettuce temperature was noticed, during 55 minutes of cold water immersion.

Data were analyzed as a split plot design, the plots corresponding to treatments and the sub-plots storage times $(0,12,24,36,48,72,96,120$ and 144 hours), in randomized block design, with four replications, a lettuce head being the experimental unit.

Lettuce heads, after selection, were submitted to following treatments: $\mathrm{T} 1=$ hydrocooling followed by storage at $5^{\circ} \mathrm{C}$ in cold chamber; $\mathrm{T} 2=$ storage in cold chamber at $5^{\circ} \mathrm{C}$ without hydrocooling; $\mathrm{T} 3=$ hydrocooling followed by storage at $22^{\circ} \mathrm{C}$ and $\mathrm{T} 4=$ storage at $22^{\circ} \mathrm{C}$ without hydrocooling. The storage of heads, for both temperatures, was performed in harvest boxes $(25 \times 48 \mathrm{~cm})$ wrapped in perforated polyethylene plastic bags, with $11 \mathrm{~mm}$ diameter holes, spaced every $10 \mathrm{~cm}$, in order to avoid excessive water loss.
Relative humidity was observed during the experiment, with final average of $55 \%$ for storage at $5^{\circ} \mathrm{C}$ and $42 \%$ for storage at $22^{\circ} \mathrm{C}$. Time from harvest until storage, after application of the treatments, was about $2 \mathrm{~h}$. Before and after application of the treatments, physical-chemical analyses were performed. Analyses performed after application of the treatments were carried out every 12 hours during the first 48 hours. Afterwards, they were carried out at every 24 hours until the end of shelf life. Except for mass loss, all other variables were statistically compared until the time when the first treatment was discarded (end of shelf life).

Accumulated fresh mass loss was estimated in relation to initial fresh mass of heads, before storage. Relative water content (TRA) was evaluated in leaf discs using the method described by Barr \& Weatherley (1962) and mentioned by Álvares et al. (2010), according to the equation: TRA $=[(\mathrm{MF}$ - MS/(MT - MS)] x 100, where: MF= fresh mass weigh $(\mathrm{g}) ; \mathrm{MS}=$ dry mass weigh (g); MT= turgid mass weigh (g). Chlorophyll content in the leaves was evaluated during storage, using leaf discs from the heads, according to the methodology described by Inskeep \& Bloom (1985), following the equation: Total chlorophyll $(\mathrm{mg} / \mathrm{L})=17.9 \mathrm{~A}_{647}+$ $8.08 \mathrm{~A}_{664.5}$.

About $5 \mathrm{~g}$ of tissue was removed from leaf limb and immersed in boiling ethanol $80 \%$ for later extraction and determination of total soluble sugar content using phenol-sulfuric method (Dubois et al., 1956). The same samples were used to determine reducing sugar contents using Somogy-Nelson method (Nelson, 1944). Non-reducing sugar content was determined by the difference between total and reducing sugars, previously determined. Residues obtained in extraction to determine total soluble sugar were dried in oven at $65^{\circ} \mathrm{C}$ and used to determine starch content. Starch extraction was performed using $52 \%$ perchloric acid, under stirring by vortex, and allowed to stand for 30 minutes and then centrifuged for 15 minutes. This operation was repeated three times and starch quantification was 
performed by the same method used to quantify total soluble sugars, and the results were expressed in percentage of dry mass.

End of shelf life was determined visually when the heads showed signs of wilt, yellowing, or decay, showing to be inappropriate for commercialization. The discard criterion established by authors was when at least $50 \%$ of the heads showed these symptoms.

Data were submitted to analyses of variance and regression. Averages for qualitative factor were grouped by the criterion of Scott-Knott (5\%). Models were chosen based on the significance of regression coefficients, using Student's t-test, adopting the 5\% level of probability for determination coefficient and biological phenomenon. Statistical analyses were carried out using statistical software SAEG, v.9.1 (SAEG, 2007).

\section{RESULTS AND DISCUSSION}

Hydrocooling of lettuce using a mixture of ice and water at $4^{\circ} \mathrm{C}$, exponentially reduced the temperature of the heads over time (Figure 1). The overall reduction in mean temperature was $12.5^{\circ} \mathrm{C}$ when reached stability. Cooling rate in the first 5 minutes was much higher than cooling rate in the following minutes $\left(2.4^{\circ} \mathrm{C}\right.$ per minute in immersion). The internal temperature of the heads before applying the treatment was, on average $20^{\circ} \mathrm{C}$, and these were cooled to $8.1^{\circ} \mathrm{C}$, after 5 minutes of hydrocooling in cold water (Figure 1), followed by a long period of stabilization of the internal temperature of the heads. Thus, 5 minutes showed to be appropriate time for application of this postharvest treatment, since from this time, the heat which was removed from heads was meaningless. The cooling curve obtained in this research was close, but not completely satisfies the theoretical curve presented by Wills et al. (2007) and mentioned by Brosnan \& Sun (2001). However, in this study, the authors observed substantial reduction in product temperature during the first minutes of hydrocooling, as proposed in the theoretical curve of

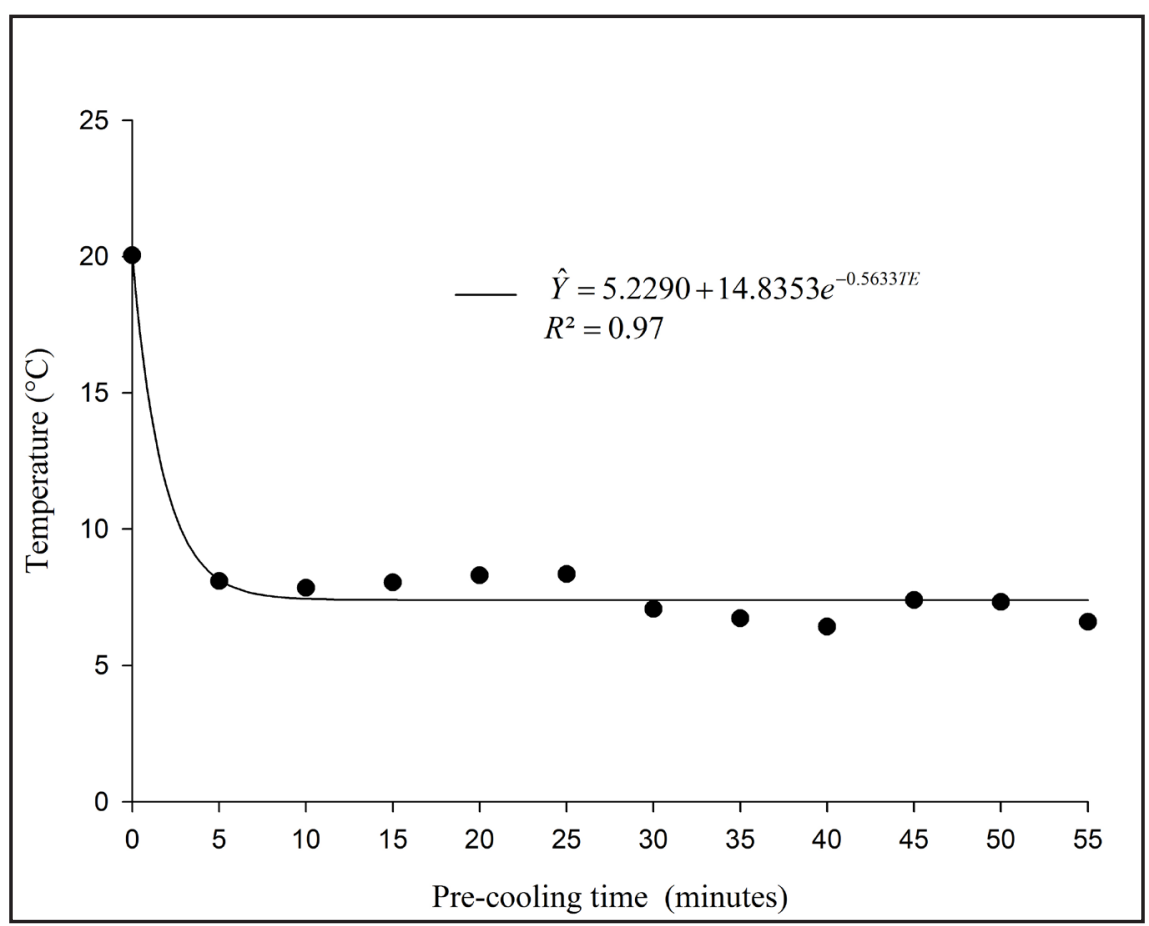

Figure 1. Mean values of the internal temperature of butter lettuce heads 'Vitória de Santo Antão' depending on pre-cooling time (TE) \{valores médios da temperatura interna das cabeças de alface lisa 'Vitoria de Santo Antão' em 'função do tempo de pré-resfriamento (TE) \}. Viçosa, UFV, 2011.

Table 1. Mean values of cumulative mass loss (\%) in butter lettuce 'Vitoria de Santo Antão' during the storage at 5 or $22^{\circ} \mathrm{C}$, with hydrocooling (HC) or without hydrocooling (no $\mathrm{HC}$ ) \{valores médios da perda de massa acumulada (\%) em alface lisa 'Vitoria de Santo Antão' durante o armazenamento a $5 \mathrm{ou} 22^{\circ} \mathrm{C}$ com ou sem hidrorresfriamento (HC) $\}$. Viçosa, UFV, 2011.

\begin{tabular}{|c|c|c|c|c|}
\hline \multirow{3}{*}{$\begin{array}{l}\text { Time after } \\
\text { storage } \\
\text { (hours) }\end{array}$} & \multicolumn{4}{|c|}{ Treatments } \\
\hline & \multicolumn{2}{|c|}{ Storage at $5^{\circ} \mathrm{C}$} & \multicolumn{2}{|c|}{ Storage at $22^{\circ} \mathrm{C}$} \\
\hline & HC & No HC & $\mathrm{HC}$ & No HC \\
\hline 0 & $0.00 \mathrm{a}$ & $0.00 \mathrm{a}$ & $0.00 \mathrm{a}$ & $0.00 \mathrm{a}$ \\
\hline 12 & $9.05 \mathrm{~b}$ & $5.00 \mathrm{~b}$ & $14.25 \mathrm{a}$ & $7.65 \mathrm{~b}$ \\
\hline 24 & $12.49 \mathrm{~b}$ & $6.83 \mathrm{~b}$ & $18.73 \mathrm{a}$ & $11.30 \mathrm{~b}$ \\
\hline 36 & $15.94 \mathrm{~b}$ & $8.48 \mathrm{c}$ & $22.90 \mathrm{a}$ & $15.92 \mathrm{~b}$ \\
\hline 48 & $17.85 \mathrm{~b}$ & $10.46 \mathrm{c}$ & $24.91 \mathrm{a}$ & \\
\hline 72 & $21.66 \mathrm{~b}$ & $13.99 \mathrm{c}$ & $34.90 \mathrm{a}$ & \\
\hline 96 & $25.06 \mathrm{a}$ & $17.36 \mathrm{~b}$ & & \\
\hline 120 & $28.55 \mathrm{a}$ & $22.67 \mathrm{~b}$ & & \\
\hline 144 & 31.58 & & & \\
\hline
\end{tabular}

Mean values followed by the same letter in the line belong to the same group by the ScottKnott test at 5\% of probability (medias seguidas de mesma letra na linha não diferem entre si pelo teste de Scott Knott a 5\% de probabilidade).

Wills et al. (2007) that means, when higher difference of temperature is present between product and cooling surroudings. Significant interaction between treatments and the storage time for fresh mass loss was noticed. Linear increase of accumulated fresh matter loss was observed during storage at 5 and at $22^{\circ} \mathrm{C}$, with or without hydrocooling (Figure 2). Similarly, linearity of mass loss was also observed during storage of scarlet eggplant (Galvão et al., 2010) at $10^{\circ} \mathrm{C}$ regardless of hydrocooling application. Higher mass 


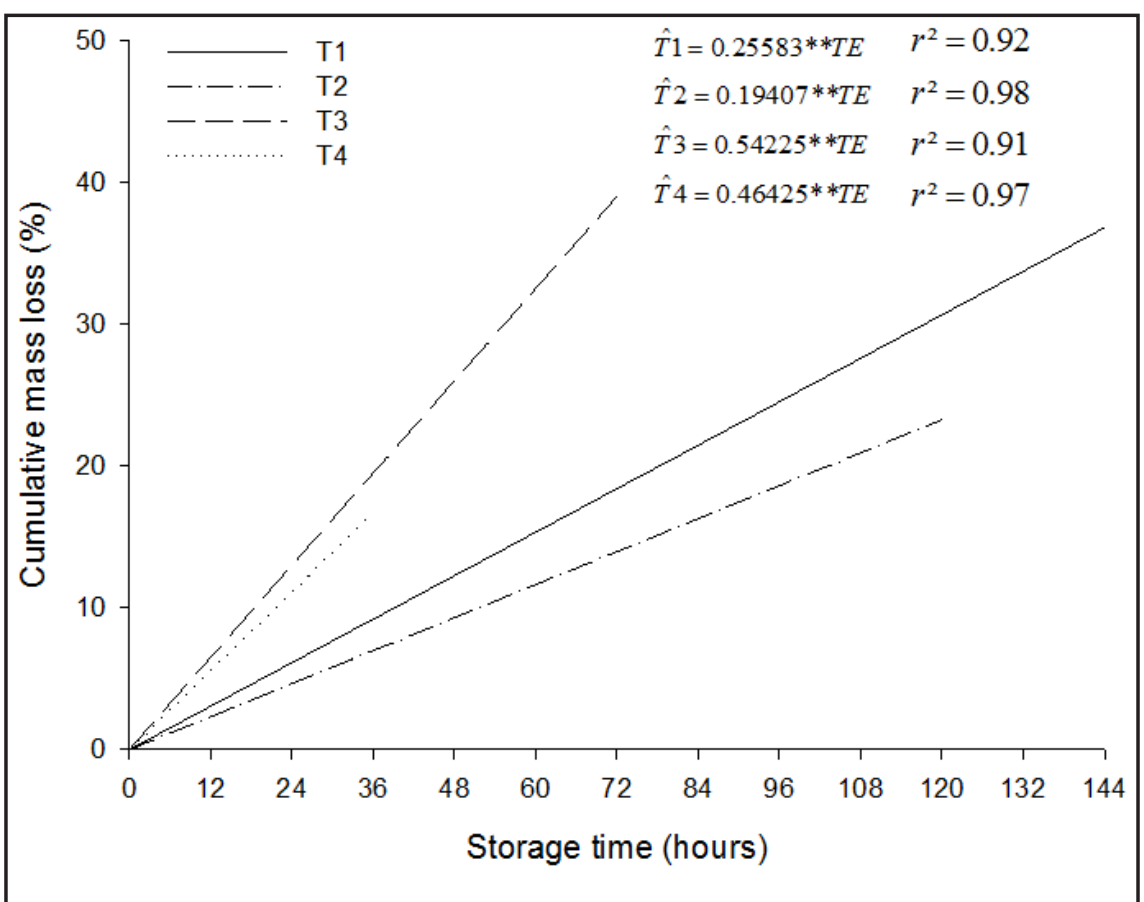

Figure 2. Estimate of cumulative mass loss (\%) of butter lettuce 'Vitória de Santo Antão' depending on time (TE) for up to 144 hours, stored at $5^{\circ} \mathrm{C}$ with and without hydrocooling (T1 and $\mathrm{T} 2$ respectively) and stored at $22^{\circ} \mathrm{C}$ with and without hydrocooling (T3 and T4 respectively) \{estimativa da perda de massa acumulada (\%) da alface lisa 'Vitoria de Santo Antão' em função do tempo (TE) por até 144 horas, armazenadas a $5^{\circ} \mathrm{C}$ com e sem hidrorresfriamento (T1 e T2 respectivamente) e armazenadas a $22^{\circ} \mathrm{C}$ com e sem hidrorresfriamento (T3 e T4 respectivamente) $\}$; **Significant at $1 \%$ by " $\mathrm{t}$ " test (significativo a $1 \%$ pelo teste t). Viçosa, UFV, 2011.

Table 2. Mean values of total chlorophyll content $\left(\mu \mathrm{g} / \mathrm{cm}^{2}\right)$ and relative water content (RWC) in butter lettuce leaves 'Vitoria de Santo Antao', stored at 5 and $22^{\circ} \mathrm{C}$, with or without hydrocooling during the first 36 hours of storage \{valores médios do teor de clorofila total $\left(\mu \mathrm{g} / \mathrm{cm}^{2}\right)$ e teor relativo de água (RWC) em folhas de alface lisa 'Vitoria de Santo Antão', armazenadas a 5 e $22^{\circ} \mathrm{C}$, com ou sem hidrorresfriamento durante as primeiras 36 horas de armazenamento $\}$. Viçosa, UFV, 2011.

\begin{tabular}{lcc}
\hline Treatments & Total chlorophyll $\left(\boldsymbol{\mu g} / \mathbf{c m}^{2}\right)$ & RWC $(\%)$ \\
\hline $5^{\circ} \mathrm{C}$ with hydrocooling & $10.32 \mathrm{a}$ & $91.87 \mathrm{a}$ \\
without hydrocooling & $10.27 \mathrm{a}$ & $88.75 \mathrm{~b}$ \\
$22^{\circ} \mathrm{C}$ with hydrocooling & $10.61 \mathrm{a}$ & $88.21 \mathrm{~b}$ \\
without hydrocooling & $10.81 \mathrm{a}$ & $86.03 \mathrm{~b}$ \\
\hline $\mathrm{CV}(\%)$ & 13.64 & 5.51 \\
\hline
\end{tabular}

Mean values followed by the same letter in the line belong to the same group by the ScottKnott test at $5 \%$ of probability (medias seguidas de mesma letra na linha não diferem entre si pelo teste de Scott Knott a 5\% de probabilidade).

loss rates were found in hydrocooled treatments in relation to their controls, without hydrocooling (Figure 2). During immersion of heads, certain amount of water has been absorbed by tissues and part was retained on the surface of leaves even after draining them. This could have contributed for higher values of mass loss observed in hydrocooling treatments, for the two storage temperatures. Gillies \& Toivonen (1995) also observed that hydrocooling can increase the mass of broccoli in 5\%, approximately.

Lettuce which was hydrocooled and stored at $22^{\circ} \mathrm{C}$ showed fresh mass loss significantly higher during storage time when compared to lettuce in other treatments (Table 1), both due to loss of water retained on the surface of the leaves and absorbed by tissues during hydrocooling application, as the higher vapor pressure gradient between the product and storage air at $22^{\circ} \mathrm{C}$. This higher gradient promotes higher respiratory and transpiratory rates and consequently higher water loss rates. Since for lettuce without hydrocooling immersing heads in water is not carried out, and therefore no absorption of water by tissues or water retention on the leaves was noticed, lower values of fresh mass loss was noticed, when storage was performed at 5 or $22^{\circ} \mathrm{C}$. For the two storage temperatures, hydrocooling promoted longer shelf life of lettuce in relation to the control without hydrocooling, for presenting more turgid leaves, visually, and with no signs of decay or senescence, essential factor for the acceptance of leafy vegetables by the consumer. When the storage was carried out at $5^{\circ} \mathrm{C}$, hydrocooling promoted an increase of $20 \%$ for shelf life, from 120 hours (5 days) to 144 hours (6 days). When the storage was carried out at $22^{\circ} \mathrm{C}$, hydrocooling promoted an increase of $100 \%$ in the shelf life, from 36 hours (1.5 days) to 72 hours ( 3 days). As in this experiment, Àlvares et al. (2010) also observed longer shelf life of parsley leaves when it was stored in a cool condition, which proves the importance of keeping the cold chain in order to preserve food security of horticultural products, regardless of hydrocooling application.

Despite hydrocooled lettuce has shown higher values of mass loss, they were visually more turgid than controls, without hydrocooling. This turgescense visually observed can be proven by higher relative water content in this lettuce (Table 2). Turgor is an essential factor in determining the shelf life of leafy vegetables. For heads stored at $5^{\circ} \mathrm{C}$, mass loss rate was $0.25 \%(6 \%$ a day) and $0.19 \%$ (4.6\% a day) for with and without hydrocooled leaves, respectively. For heads stored at $22^{\circ} \mathrm{C}$, mass loss rate per hour was higher, $0.54 \%$ (13\% a day) and $0.46 \%$ (11\% a day) for with and without hydrocooled treatments, respectively. This fact is due 
to higher vapor pressure gradient among leaves and storage conditions at $22^{\circ} \mathrm{C}$ compared to storage at $5^{\circ} \mathrm{C}$. The highest vapor pressure gradient promotes higher respiratory and transpiratory rates and, consequently, higher water loss rates (Finger \& França, 2011).

Effect of storage time on relative water content in leaves was not noticed, however treatment effects for this variable were observed. Hydrocooled lettuce stored at $5^{\circ} \mathrm{C}$ showed relative water content significantly higher than the control without hydrocooling (Table 2 ). These data support the increased leaf turgescense and freshness appearance observed during storage, and therefore, longer shelf life for this lettuce. Álvares, et al. (2007), studying the effect of precooling for parsley, observed higher relative water content in hydrocooled leaves, when compared to control, during all storage time at $5^{\circ} \mathrm{C}$. When the storage was carried out at $22^{\circ} \mathrm{C}$, no effect of hydrocooling in relative water content of lettuce was observed (Table 2), which can be explained by higher vapor pressure gradient established in this storage temperature accelerating water loss of leaves. The hydrocooling followed by storage at $5^{\circ} \mathrm{C}$ is an effective technique to maintain the leave water balance, keeping these leaves hydrated for a longer period of time during storage.

No effect of treatment and storage time was observed for chlorophyll content in the leaves. Average value of chlorophyll content in the leaves was $10.5 \mu \mathrm{g} / \mathrm{cm}^{2}$ (Table 2). The same way, Álvares et al. (2007) did not find any changes in chlorophyll content in parsley leaves during the 144 hours of storage at $5^{\circ} \mathrm{C}$ using SPAD index.

No effect of treatment and treatment $\mathrm{X}$ storage time interaction was observed for total soluble sugar, reducing sugar, non-reducing and starch contents in lettuce leaves during the first 36 hours of storage. The authors noticed linear reduction in total soluble sugar content during storage of lettuce $(\hat{\mathrm{Y}}=0.6544$ $\left.0.006214 * \mathrm{TE} ; \mathrm{R}^{2}=0.58\right)$. Regardless of the treatment used there was no change for reducing sugar contents, with a mean value of $0.34 \%$ during storage. For starch contents, the authors noticed an exponential decrease of this reserve carbohydrate $\left(\hat{\mathrm{Y}}=0.434662 \mathrm{e}^{-0,477443^{*} \mathrm{TE}}\right.$; $\left.\mathrm{R}^{2}=0.67\right)$, with significant decrease in the first 12 hours of storage, time in which there is a greater demand for carbohydrates to supply high respiratory rates (Aguila et al., 2006). Linear reduction in non-reducing sugars during 36 hours of storage $(\hat{\mathrm{Y}}=0.300698$ $\left.0.00541922 * \mathrm{TE} ; \mathrm{R}^{2}=0.94\right)$ was noticed, probably due to conversion of sucrose (main non-reducing sugar) into glucose and fructose to be used as energy source in cellular respiration. Álvares et al. (2007) also did not find hydrocooling effect in contents of these carbohydrates in parsley leaves. Starch was the carbohydrate present in higher quantity in leaves (data not shown) in comparison to soluble sugars, although leafy vegetables do not show, in general, a large amount of these carbohydrates, which reduces storage potential of these products.

Hydrocooling promoted longer shelf life of this lettuce type, in storage at 5 and $22^{\circ} \mathrm{C}$ and kept higher water content in leaves stored at $5^{\circ} \mathrm{C}$. The authors proved the importance of keeping the cold chain in order to increase shelf life, regardless the application of other treatment for postharvest conservation.

\section{ACKNOWLEDGEMENT}

The authors thank to CNPq (National Council for Scientific and Technological Development) for providing doctorate course scholarship for Christiane de Fátima Martins França.

\section{REFERENCES}

AGUILA JS; SASAKI FF; HEIFFIG LS; ORTEGA EMM; JACOMINO AP; KLUGE RA. 2006. Fresh-cut radish using different cut types and storage temperatures. Postharvest Biology and Technology 40: 149-154.

ÁLVARES VS; FINGER FL; SANTOS RCA; SILVA JR; CASALI VWD. 2007. Effect of pre-cooling on the postharvest of parsley leaves. Journal of Food, Agriculture \& Environment 5: 31-34.

ÁlVARES VS; RAMOS PAS; MAPELI AM; FINGER FL. 2010. Pré-resfriamento e embalagem na conservação de folhas de salsa. Brazilian Journal of Food Technology
13: 107-111.

BAR HD; WEATHELEY PE. 1962. A reexamination of the relative turgidity technique for estimating water deficit in leaves. Australian Journal of Biological Sciences 15: 413-428.

BROSNAN T; SUN DW. 2001. Precooling techniques and applications for horticultural products - a review. International Journal of Refrigeration 24: 154-170.

DUBOIS M; GILLES KA; HAMILTON JK; REBERS PA; SMITH F. 1956. Colorimetric method for determination of sugars and related substances. Analytic Chemistry 28: 350-356.

FINGER FL; ÁlVARES VS; SILVA JR; CALESTINE C; CASALI VWD. 2008. Influence of postharvest water replacement on shelf life of parsley leaves. Journal of Food, Agriculture \& Environment 6: 116-118.

FINGER FL; FRANÇA CFM. 2011. Préresfriamento e conservação de hortaliças folhosas. In: Congresso Brasileiro de Olericultura, 51. Horticultura Brasileira 29.

FINGER FL; VIEIRA G. 1997. Controle da perda pós-colheita de água em produtos hortícolas. Viçosa: UFV. 29p. (Caderno didático, 19).

GALVÃO HL; CRUZ SM; FRANÇA CFM; CÔRREA PC; FINGER FL. 2010. Qualidade de jilós pré-resfriados e embalados com filme de PVC armazenados sob refrigeração. Revista Brasileira de Armazenamento 35: 138-144.

GILLIES SL; TOIVONEN PMA. 1995. Cooling method influences the postharvest quality of broccoli. HortScience 30: 313-315.

INSKEEP WP; BLOOM PR. 1985. Extinction coefficients of chlorophyll $a$ and $b$ in N, N Dimethylformamide and $80 \%$ acetone. Plant Physiology 7: 483-485.

KADER AA. 2010. Handling of horticultural perishables in developing vs. developed countries. Acta Horticulturae 877: 121-126.

LILL RE; KING GA; O'DONOGHUE EM. 1990. Physiological changes in asparagus spears immediately after harvest. Scientia Horticulture 44: 191-199.

NELSON N. 1944. A photometric adaptation of Somogyi method for determination of glucose. Journal Biology Chemistry 135: 136-175.

SAEG. Sistema para análises estatísticas e genéticas. 2007. Versão 9.1. Viçosa: Fundação Arthur Bernardes.

TOIVONEN PMA. 1997. The effects of storage temperature, storage duration, hydro-cooling, and micro-perforated wrap on shelf life of broccoli (Brassica oleracea, italica group). Postharvest Biology and Technology 10: 59-65.

VILELA NJ; LANA MM; NASCIMENTO EF; MAKISHIMA N. 2003. O peso da perda de alimentos para a sociedade: o caso das hortaliças. 2003. Horticultura Brasileira 21: 141-143.

WILLS R; McGLASSOM B; GRAHAM D; JOYCE D. 2007. Postharvest: and introduction to the physiology and handling of fruit, vegetables and ornamentals. $5^{\text {th }}$ ed. New South Wales: University of New South Wales Press. 227p. 